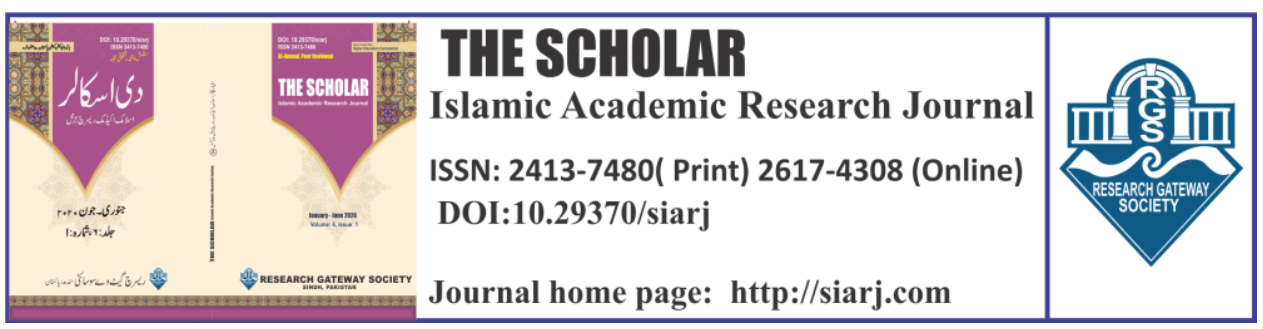

\title{
ACHIEVING THE TRUE PURPOSE OF EDUCATION: ROLE OF CURRENT SYSTEM OF EDUCATION AND ISLAMIC VIEWPOINT
}

\section{Aziz-ur-Rehman Saifee}

Assistant Professor, Department of Arabic, University of Karachi, Pakistan Email: Aziz.rehman@uok.edu.pk ORCIID IID:

https://orcid.org/0000-0003-2324-2718

\section{Nasir Majeed}

Registrar, PAF Air War College, Karachi, Pakistan

Email:nasirmajeed484@gmail.com

ORCIID IID:

https://orcid.org/0000-0003-4992-9171

\section{Qari Badaruddin}

Assistant Professor, Department of Arabic, Federal Urdu University, Karachi, Pakistan

Email: drqaribadaruddin@gmail.com

ORCID IID:

https://orcid.org/0000-0003-0250-1602

To cite this article:

Saifee, Aziz-ur-Rehman, Nasir Majeed, and Qari Badaruddin. "ACHIEVING THE TRUE PURPOSE OF EDUCATION: ROLE OF CURRENT SYSTEM OF EDUCATION AND ISLAMIC VIEWPOINT." The Scholar-Islamic Academic Research Journal 6, no. 1 (May 31, 2020): 220-231. To link to this article: https://doi.org/10.29370/siarj/issue10ar15

\begin{tabular}{|c|c|}
\hline Publisher & $\begin{array}{l}\text { The Scholar Islamic Academic Research Journal } \\
\text { Vol. 6, No. } 1 \text { || January -June } 2020 \text { || P. 220-231 } \\
\text { Research Gateway Society }\end{array}$ \\
\hline DOI: & $\underline{10.29370 / \text { siarj/issue } 10 \operatorname{ar} 15}$ \\
\hline URL: & https://doi.org/10.29370/siarj/issue10ar15 \\
\hline License: & Copyright c 2017 NC-SA 4.0 \\
\hline Journal homepage & www.siarj.com \\
\hline Published online: & $2020-05-31$ \\
\hline
\end{tabular}

$$
\text { (c) }(1) \text { (1) (2) }
$$

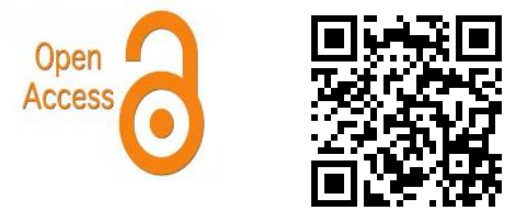


THE SCHOLAR (January- June 2020)

\title{
ACHIEVING THE TRUE PURPOSE OF EDUCATION: ROLE OF CURRENT SYSTEM OF EDUCATION AND ISLAMIC VIEWPOINT
}

Aziz-ur-Rehman Saifee, Nasir Majeed, Qari Badaruddin

\begin{abstract}
:
The study will highlight the core problems of a society that arise with the deficiency of a proper mode of education. Also, this research will emphasize the problems associated with the improper implementation of the current system of education and those that the current system has failed to encounter. It will provide an Islamic perspective in the light of the achievements it has had in the construction of a society in the past with emphasis laid on the background of those societies. The thesis will also highlight the aspects of application of Islamic ideas to a true purpose of education and its feasibility for the environment of the present day society and its pace of modernization. The research will be based on qualitative approach listing the facts to reach a conclusion. Previous thesis, relevant books, expert opinions and internet researches will be used to gather the facts in the process of this study. The qualitative scheme is preferred over the quantitative as the amount of knowledge about the Islamic ideology in general public, in devising an opinion about the Islamic motives, is questionable. Therefore, any conclusion formulated on the basis of the information collected from the surveys and opinion polls will be highly unjustified.
\end{abstract}

KEYWORDS: Education system, Current System, Islamic system of Education, Problems with the Current system, Problems with the Islamic system, Objective of Education 


\section{INTRODUCTION}

The success of a type of education can be judged by the accomplishments it has had in bringing about a positive change in the society. Positive change, in the sense, whether the education system has contributed in the society with implementation of rule of law, social uplifting, economic success and establishment of peace and security. Today the Pakistani society and the world are deficient of the said positive changes. The current system of education has failed to execute its true purpose. Whether or not the system would have succeeded in its goals to meet the requirements of the society if it had been properly implemented, is the question answered during the course of this study. The topic is of core importance because education is the key to success for any society. Thus, determining the kind of education to be provided to the people of a society is essential for the positive and most effective outcome from that education. The research topic addresses the fields concerning the system of education prevalent in the world today, the success they have had in bringing about a peaceful society and a healthy alternative to those systems particularly the Islamic system of education. The Islamic standpoint on this subject is too thorough to be ignored as the Islamic era has witnessed a vast age of reasoning and intellect. With the Islamic values injected into the system of education of that era, it served to raise a society which excelled in all aspects of the positive change discussed earlier. Whether or not the Islamic stance holds the capability to be practiced in today's society and will it bring about a positive change today in the light of the fact that the world is moving towards modernization at an amazing pace, is a question that this research tries to answer. Due to lack of knowledge regarding Islamic ideals, the Islamic perspective of true 
purpose of education is readily rejected without gaining insight into its approach and mechanism that follows.

\section{THE TRUE PURPOSE OF EDUCATION}

We know from history that the procurement of knowledge is a goal shared by all nations of the world and that this common objective does not expire by boundaries, culture or time. The motive behind this aim is the fact that education is the foundation for any successful society. Therefore, it is imperative to determine what type of education is to be provided to a society. During the course of time many systems of education have evolved which assert that they possess the correct method of delivering education. However, not many have succeeded in their cause. The success of the system of education can be reflected from the condition of the society in which that system has been implemented.

The first step in adjudicating any system of education on its course to deliver knowledge to the people of a society is to define, what the objective of education should be, in that social order. Some think that education is a method of attaining the correct means of exploitation, so that they can bring about mass destruction. While others think that it is a way to achieve successful conclusions in life rather than the means to successful conclusions. The function of education should be, to enable a man to think creatively, logically and intensively which would facilitate him to achieve the legitimate goals of his life, rather than to be a utility.

Many of the so called educated societies do not think intensively and logically enough to eliminate racial discrimination, slavery and prejudice amongst them. Education should develop in a person the ability to distinguish between right and wrong, the truth from falsehood and facts 
from fiction. But the true purpose of education should not stop at efficiency, which would prove to be a nuisance for a society. Intelligence alone is not enough. The complete education is intelligence plus character - which would not only provide with the power of concentration but will also give worthy objectives upon which to ponder. We must remember that the most dangerous criminal mind can be of a person gifted with reason but with no moral character. ${ }^{1}$

This complete education will not only provide the people of a society with a vast wealth of knowledge but also with the ability to live their lives in social harmony and peace.

\section{THE CURRENT SYSTEM OF EDUCATION}

The current system of education consists of a series of stages that one must consider as rites of passage in order to achieve a higher prestige in the modern society. The system of education discussed here is the common scheme charted by most of the countries of the world. Its approach to knowledge can be divided into two parts.

1) General Education

2) Professional and Technical education

The General Education can be further divided into three phases:

1) Primary Education

2) Secondary Education

3) Higher Education

1 - Junior, Dr. Martin Luther King. 1947. The True Purpose of education. Morehouse College Paper.

http://www.drmartinlutherkingjr.com/thepurposeofeducation.htm. 
Any person seeking knowledge and skills have to pave their way through these stages in order to have a chance at quality life. Moral education is a part of the syllabus in some countries. And it is taught somewhere between primary and secondary phases. As far as the primary education is concerned, its major aim is to provide pupils with basic literacy and numeracy skills. It also lays the foundation in mathematics, geography, history and science. A lot of concentration is to be given to this part of education as all the stages in this phase are of great importance. The secondary education takes the subjects of the primary into understanding phase and develops basic analytical skills. The higher education is a phase when pupils are to follow a specific field of education based on their choice of the field of interest. After this, comes the professional and technical education, where they select the universities or professional institutions to go to, for their chosen fields. The professional institutions provide all the facilities for their technical studies. ${ }^{2}$

The system succeeded in producing some of the smartest men of the society but failed to provide a smart and peaceful society to the world.

\section{PROBLEMS ASSOCIATED WITH THE CURRENT SYSTEM OF EDUCATION}

The very basis of this system's concept of departing education is flawed. It is designed to produce skilled workforce who should be able to satisfy the appetite of an employer or state. Thus, it sees education as a service sold to the students who along with their parents are customers of this system. It considers it as an article of trade. Therefore, the fate of education rests in

2 - Natiq, Prof. Abdul Qayyum. 2004. Sirate Mustaqim. Karachi: Fareedi Publisher . 


\section{Achieving the true purpose of education: role of current system of education and Islamic viewpoint}

the hands of the employer. No job, no education. Moreover, the system has been designed to run in the most ideal conditions, not taking into account the various changing environment factors like the lack of funds, condition of state etc. This very education becomes a burden on the government in the state of economic depressions or recovery after wars or catastrophe when there is unemployment and the citizens have no defined roles to play.

The second problem with this system is that it pays no or little heed to the development of moral education. As the job article in the newspaper does not place the moral education as the criterion for a high paid job, it is considered as an extracurricular activity in most of the educational institutions. Also, the moral education provided to students isn't up to the mark of what is required in the society. The effort to try to provide education at a very early stage so as to morally develop the students from the beginning is good, but stopping there is proving to be counterproductive. That too is only the case in some of the countries where moral education is actually introduced up to some level.

The third issue is the amount of attention paid to the primary sector of education. Due to its importance, its development should have been allotted more effort and budget. But unfortunately, its importance is attended to by only a few of the nations of the world. Poverty, lack of facilities and being a third world nation are all the factors accounting forthe least amount of effort dedicated to this sector by many countries of 
the world. ${ }^{3}$

The secondary and higher education is a test preparation phase for the professional and technical education institutes.

One of the most important issues is the high cost and a very high grade threshold laid for the entrance to these institutions, for the educational "services" they claim to provide. This limits professional education to only a few students of the privileged class. Thus, the drop outs or the students with no professional education are greater in number. They are destined to work in low-waged jobs, and in poorer countries, some even lose their last gamble at a decent life. This issue forces a large number of people to settle for all kinds of means, both acceptable and inacceptable, in order to gain a higher status in society. As moral education was already low, most people are indulged in inappropriate activities (alcoholism, adultery, crime, terrorism etc.) which serve the role of a termite to the wooden foundation of any society. Thus, whether or not the system had been implemented properly, its end result wouldn't be prolific enough to any society's advantage. $^{4}$

\section{THE ISLAMIC IDEOLOGY OF THE SYSTEM OF EDUCATION}

When we survey the system of education in an Islamic society chalked out by their ancestors we are compelled to commend them. The foundation of

3 - Tirmazi, Shamim Haider. n.d. "A Historical Study of the Islamic system of Education." Research Repository, Bahauddin Zakariya University. http://eprints.hec.gov.pk/480/1/202.html.htm.

4 - Seggie, Fatma Nevra. 2009. Islam and Higher Education in Transitional Societies. www.islamiceducationonline.blogspot.com. 


\section{Achieving the true purpose of education: role of current system of}

education and Islamic viewpoint

this system of education was laid on the basis of the teachings of Quran and Sunnah. It considers education to be a human right rather than a mere utility or the means of exploitation. It may be defined as a system which transmits the veiled and acquired knowledge to the younger generation of Muslims in order to prepare them for life and enable them to discharge their duties as (Vicegerent or Agent) of God on this earth with the sole aim of achieving success here and in the hereafter. Islamic education is a total and complete system which does not separate the mundane affairs of life from the moral and spiritual aspects. ${ }^{5}$

It laid much stress on primary education, and every town, village and hamlet were provided with facilities and arrangements for the children's education. For instance, there were schools called Maktabs in every mosque and Imam performed the duties of the teacher. Both boys and girls from every single household received compulsory and free education in these institutions.

There was no distinction of rich and poor, white or black, Muslim or nonMuslim and teachers did not accept any remuneration for work. For this reason, the teachers received capital respect from not only the students but from every member of the society. The teacher was considered as the symbol of success of that society.

There was a syllabus prescribed as well including the rules of cleanliness, discipline in Maktabs, etiquettes of eating and drinking, of mutual contact, social behavior and matters of everyday life were taught apart from the

5 - Anderson, Khadija. 2008. Western Education vs. Muslim Children. http://www.jannah.org/articles/westernedu.html. 


\section{Achieving the true purpose of education: role of current system of}

education and Islamic viewpoint

general education. The Muslims were taught Quran in Arabic while other subjects were taught in the local language.

The procedure followed for the departing of education to the local population was so successful that the literacy rate in its true sense was $100 \%$. There were hundreds of libraries built in every major capital of the Islamic empire. Libraries in Baghdad and Cordoba boast a collection of more than 400,000 books. ${ }^{6}$

The system worked even though the Islamic society underwent a lot of changes. This was due to the fact that the driving force of this system of education was not money or high end jobs. But it was merely to produce humans with a wealth of knowledge and immense moral education for that knowledge's application. It was aimed at producing humans who would take up the responsibility to bring about a productive change in the society. Humans, who would selflessly, support the government or state in times of hardship. Humans, who would by themselves, lend a helping hand to the poor and needy, thus uplifting the huge burden of the government and set the society en-route to eradicate poverty. ${ }^{7}$

${ }^{6}$ - Al-Attas, Syed Muhammad Naquib. n.d. The Concept of Education in Islam.

7 - Sanjakdar, Ms. Fida. n.d. A Study of the Hidden and Core Curriculum of an Islamic school. http://www.aare.edu.au/01 pap/san01187.htm. 


\section{PROBLEMS ASSOCIATED WITH THE ISLAMIC PERSPECTIVE}

The only major issue with the Islamic system of education is that, in order to benefit from its fruits to the fullest, it must be employed in a state where Islamic Law (Sharia) is implemented. Otherwise, it would produce the said educated humans but they won't have the platform to exercise their abilities effectively and bring about a fruitful change in society. Although addressing this issue would result in a significant positive transformation in the society, nevertheless, the system could still work and prove to be productive to any system of government. Another issue is that all Madrassah systems of education are linked to the Islamic system of education. Thus, any misconduct on the part of these Madrassahs is directly associated with the Islamic system of education. It must be noted that while some Madaris are effectively following the Islamic system of education, others are simply a business model looking forward to monetary gains. Associating these Madrassahs to Islamic System is highly unfair as the Islamic System cannot perform a double role. If it has provided the society with model human beings, then it can't be related to the corrupt institutions that have their objectives in the wrong directions.

\section{IMPLEMENTATION OF THE ISLAMIC SYSTEM OF EDUCATION IN TODAY'S MODERN WORLD}

The Islamic system of education does not expire by location and time. The proof is the fact that it has been practiced for more than a thousand years and has been implemented in the vast region of the Islamic Empires, ranging from Spain in the west to South China Sea in the East. It has been able to produce the likes of Al Beruni, Ibn- e-Sina (Avicenna, author of 
The Scholar Islamic Academic Research Journal

Vol. 6, No. 1 || January-June 2020 || P. 220-230

https://doi.org/10.29370/siarj/issue10ar15

the world famous "Canon of Medicine"), Al Jazari (the inventor of the first human serving robots and laid the foundation of the modern function of robots), Al Jabir (the architect of Algebra) and many more. These people are the product of the system implemented in different parts of the world. They are a proof that the Islamic system of education has the ability to be implemented in the modern world.

\section{CONCLUSION}

The superiority of the Islamic system of education is evident from this thesis. It has proved every bit of itself to be more competent than any other system of education existent on this planet. Not only the Islamic society, but any society of the world would benefit from the fruits of this system of education if properly implemented.

\section{(C)(1)(0)}

BY NC SA This work is licensed under a Creative Commons

Attribution-NonCommercial-ShareAlike 4.0 International (CC BY-NC-SA 4.0) 